\title{
Trends Research and Publication of Master Students in Science Education Program
}

\author{
${ }^{1 *}$ Eko Hariyono, ${ }^{1}$ Titin Sunarti, ${ }^{2}$ Fenny Roshayanti, ${ }^{1}$ Hasan Nuurul Hidaayatullaah, \\ ${ }^{1}$ Desi Wulandari \\ ${ }^{1}$ Science Education Postgraduate Program, Universitas Negeri Surabaya \\ Jl. Lidah Wetan, Lidah Wetan, Kec. Lakarsantri, kota Surabaya, Jawa Timur 60213 \\ ${ }^{2}$ Science Education Postgraduate Program, Universitas PGRI Semarang \\ Jl. Sidodadi Timur No.24, Karangtempel, Kec. Semarang Tim., Kota Semarang, Jawa Tengah \\ 50232 \\ *Corresponding Author e-mail: ekohariyono@unesa.ac.id
}

Received: December 2021; Revised: January 2022; Published: January 2022

\begin{abstract}
College students' creativity can be seen based on the novelty of research. The main objective of this study was to analyze trends research and publicationof the master of science education at the State University of Surabaya. The descriptive qualitative method used in this study. The data of this study collected by analyse the last five years research abstracts from 2015 to 2020. The data obtained were analyzed using a total sampling technique. Research trends and publication in the Master of Science education at the State University of Surabaya are mostly researching about the development of learning tools with qualitative-quantitative methods and research topics about innovative learning in the field of thinking skills. Some college student research uses curriculum topics, learning media, and assessments. While the publication trend is obtained by analyzing the publication of student articles resulting from the thesis based on the analysis of publications in the category of international and national journals. Department heads need policy recommendations in making decisions to improve research trends and college student publications. current study result implies that research trends in the Master of Science education at the State University of Surabaya require further innovation.
\end{abstract}

Keywords: Trends research, thesis, publications, topics research, postgraduate science education

How to Cite: Hariyono, E., Sunarti, T., Roshayanti, F., Hidaayatullaah, H., \& Wulandari, D. (2022). Trends Research and Publication of Master Students in Science Education Program. Prisma Sains : Jurnal Pengkajian Ilmu dan Pembelajaran Matematika dan IPA IKIP Mataram, 10(1), 104-114. doi:https://doi.org/10.33394/jps.v10i1.4820

https://doi.org/10.33394/j-ps.v10i1.4820

Copyright $\odot$ 2022, Hariyono et al This is an open-access article under the CC-BY License.

\section{INTRODUCTION}

The thesis is a research-based scientific paper written by postgraduate students compiled and recorded by the writing guidelines applicable at the university. The thesis can be used as a reference in developing knowledge (Ruhaliah \& Hernawan, 2019; Meza \& Nascimento, 2018). Besides being used as a graduation requirement, the thesis can be used to measure research progress (Sarirah \& Saputri, 2019). With the writing of scientific papers or theses, college students will be motivated to solve problems and create solutions in their respective fields (Laptev \& Larchenkova, 2016; Rachmatullah et al., 2016; Shustin et al., 2019; Susetyo \& Noermanzah, 2020). So the thesis is an administrative requirement and is used as a reference in developing research.

A good thesis is a completed thesis. This statement is not entirely true, but something important is being an innovative researcher and creating new ideas (Rachmatullah et al., 2016; Wulandari et al., 2019). Writing a thesis is not only imitating what others have written, but it is necessary to correct it, then develop it into new research. The thesis can be written by developing previous research and creating discoveries. Becoming an excellent student by 
creating new findings is hope for researchers, especially at the education level (Hammond, 2021; Rosba et al., 2021).

Most students prepare their thesis by adapting previous findings or researching things that other students often research. This makes the title of thesis writing less varied. Most college students did not dare to formulate new ideas because it was difficult to get references (Asmawan, 2017). Therefore, most universities tend to research the same thing. These issues are often encountered in universities. Most college students are doing development research, some are doing applied research. Furthermore, the research focus taken is almost the same as the previous research. Students are less courageous in taking different topics because they are afraid it will take them a long time to complete their studies (Birney et al., 2021; Brata, 2015).

College students need to explore their ideas orally and in writing thesis. Creating creative ideas is a skill that needs to be developed in the 21st century (Daud et al., 2012; Desi Wulandari, 2019). In addition to creating ideas, developing the suitable method is needed in writing a thesis. The scientific method plays a crucial role in determining the feasibility of a study (Barrot et al., 2020; Greenberg, 2015), so the scientific method in each research is different.

With the low ability to find research novelties and students' weak mastery of research methodologies, it is necessary to analyze the mapping of student thesis profiles. Sudarisman (2013) stated that students tend to use the same methodological technique, namely documentation, while there is other information that students can explore in designing their final project. The research shows that students tend not to dare to use the novelty of research, so a trend analysis of student thesis is carried out. And ideally, the new things created by students are able to improve the policies and quality assurance of the institution. From this analysis, this study aims to analyze the mapping of the thesis profile of postgraduate students (master) in Science Education. The purpose of mapping college student thesis profiles and publications is to improve research performance. This research can be used as a point of view for universities to create new and varied research.

\section{METHOD}

\section{Research Design}

This research is qualitative descriptive research on the thesis of Master's Degree students of Science Education Study Program, Postgraduate Program State University of Surabaya. The data collection process was carried out by collecting thesis abstracts for the last five years, namely 2015 to 2019. Collected data were analyzed using the total sampling technique. Each of the collected abstracts is identified based on: type of research, research area discussed, topic category and its up-to-date references, and college student publications.

In more detail, the thesis abstract will be identified according to each category as follows:

- Type of research, grouping theses into groups: qualitative or quantitative research, development or application research, or mixed research (mix method).

- Categories of topics into groups: Curriculum, Innovative Learning, Learning Media, and Assessment.

- The research areas discussed are scientific literacy, critical thinking, HOTs, ESD, STEAM, and assessment.

- Reference categories based on 30 references of the last 10 years

- The publisher identifies the type of publication

\section{Sample Research}

This research was conducted on the thesis abstracts of S2 students of the Science Education Study Program, Postgraduate State University of Surabaya, for the last 10 years, namely in the period 2015 to 2019. 


\section{Procedure of Research}

- Observ SIAKADU data and recap of Universitas Negeri Surabaya (Unesa) postgraduate library thesis data to obtain student thesis data (thesis abstract) for the last 5 years.

- Read each thesis abstract carefully to identify each thesis into the category of research type, research field, topic category, the novelty of references, and the type of publication chosen by students.

- Present data into tabulated tables and stating percentages according to categories.

- Present data in graphical form for easy reading.

- Describe the results of data analysis that have been obtained.

- Provide a discussion of the research results obtained. Prepare policy recommendations to the study program leaders in making decisions to take intervention actionsto improve the quality of student thesis writing and publications by the superior fields of the Master of Science Education study program.

\section{Data collection technique}

Research data in the form of thesis abstracts of students of the Science Education Study Program were explored from the Integrated Academic Information System (SIAKADU) through the study program admin and the Unesa postgraduate library. Furthermore, information is identified based on: the type of research, the research subjects discussed, the topic category and its up-to-date references, and the level of student publications.

\section{Data Analysis Technique}

Data analysis was carried out on student academic achievement as seen from the GPA at graduation. The data were analyzed using the following techniques.

- Explore the SIAKADU and Unesa Postgraduate library archives to collect thesis data .

- Abstracts were grouped by: type of research, the field of research, topic category, and novelty of references and publications.

- Tabulates data, presents data in percentage proportions and graphs, and describes research data.

- Formulate the recommendations

\section{RESULTS AND DISCUSSION}

\section{Trends in Thesis Profile of S2 Science Education Students}

The research trends of master's degree student thesis research in science education in 2015-2020 based on identification according to research categories, namely the type of research, research topic, and research field, are presented in percentage form in Table I.

Table 1. Type Styles Trends in Student Thesis by Research Category

\begin{tabular}{lllllll}
\hline \multirow{2}{*}{ Research Category } & \multicolumn{3}{c}{ Frequency } & & & \\
Types of research & Implementation & 0 & $\mathbf{2 0 1 6}$ & $\mathbf{2 0 1 7}$ & $\mathbf{2 0 1 8}$ & $\mathbf{2 0 1 9}$ \\
& Development & 13 & 10 & 0 & 0 & 0 \\
Research topic & Curriculum & 0 & 0 & 0 & 0 & 0 \\
& Innovative learning & 10 & 10 & 26 & 22 & 8 \\
& Learning Media & 0 & 0 & 3 & 1 & 1 \\
& Assessment & 3 & 1 & 1 & 4 & 1 \\
Area of Research & Science literacy & 0 & 2 & 1 & 0 & 3 \\
& Thinking Skills & 7 & 6 & 23 & 19 & 5 \\
& HOTs & 0 & 1 & 3 & 0 & 0 \\
& ESD & 0 & 2 & 0 & 1 & 0 \\
& STEAM & 0 & 0 & 0 & 0 & 0 \\
& Assessment & 2 & 90 & 0 & 4 & 2 \\
& Other & 4 & 0 & 3 & 3 & 0 \\
\hline Total each category & & 13 & 11 & 30 & 27 & 10 \\
\hline
\end{tabular}


Based on Table I, it can be seen that S2 science education students for the 2015-2019 period mostly used the type of development research in the last five years. The tendency of student thesis profiles based on research topics grouped into four topics shows that students tend to conduct innovative learning development research. In Table 1, students are less interested in researching research topics about learning media and assessments. Even the topic of the curriculum was not touched at all. Meanwhile, if viewed based on the research areas grouped into seven research areas, it can be seen that the tendency of student research profiles tends to be in the area of thinking skills. The STEAM research field group was not touched at all in 2015-2020.

\section{Thesis Profile Trends by Topic Category and Research Type}

Trends in student thesis research based on the identification of topic categories and types of research in 2015-2019 are shown in Figure1 as follows.

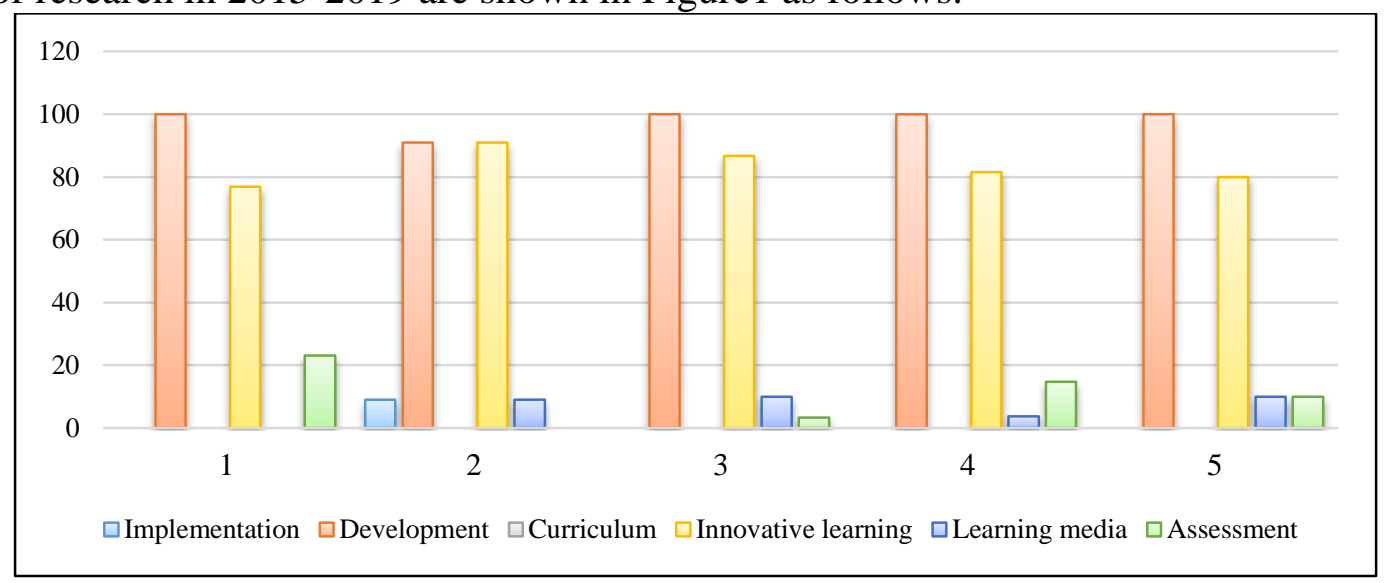

Figure 1. Graph of thesis profile percentage based on topic category and research type

Figure 1 shows that the majority of masters in science education from 2015 to 2019 used the type of development research. The development research studied by students mostly focuses on developing learning tools by innovating learning from applied learning models. Therefore, it can be seen in Figure. 1 that the majority of student research topics are on the topic of innovative learning research and very few students focus on the topic of learning media and assessments. The topic of the curriculum was not even touched by the masters of science education in conducting their final project research in 2015-2019.

Master of Science Education students uses the type of development research because they want to further explore and apply their scientific field by creating research novelties. Development. Zulkifli et al (2015) that there is an increasing trend in topics related to media development and learning tools in the science education master's program. In line with research conducted by Zhang (2020), which states that research on themes and trends in the development of Mobile Learning in the last ten years has become the focus of student research.

\section{Thesis profile trends by category of the research field and reference update}

The trend of thesis profile trends for masters in science education based on research field categories grouped into seven groups is presented in the form of percentages from each year in Figure 2. 


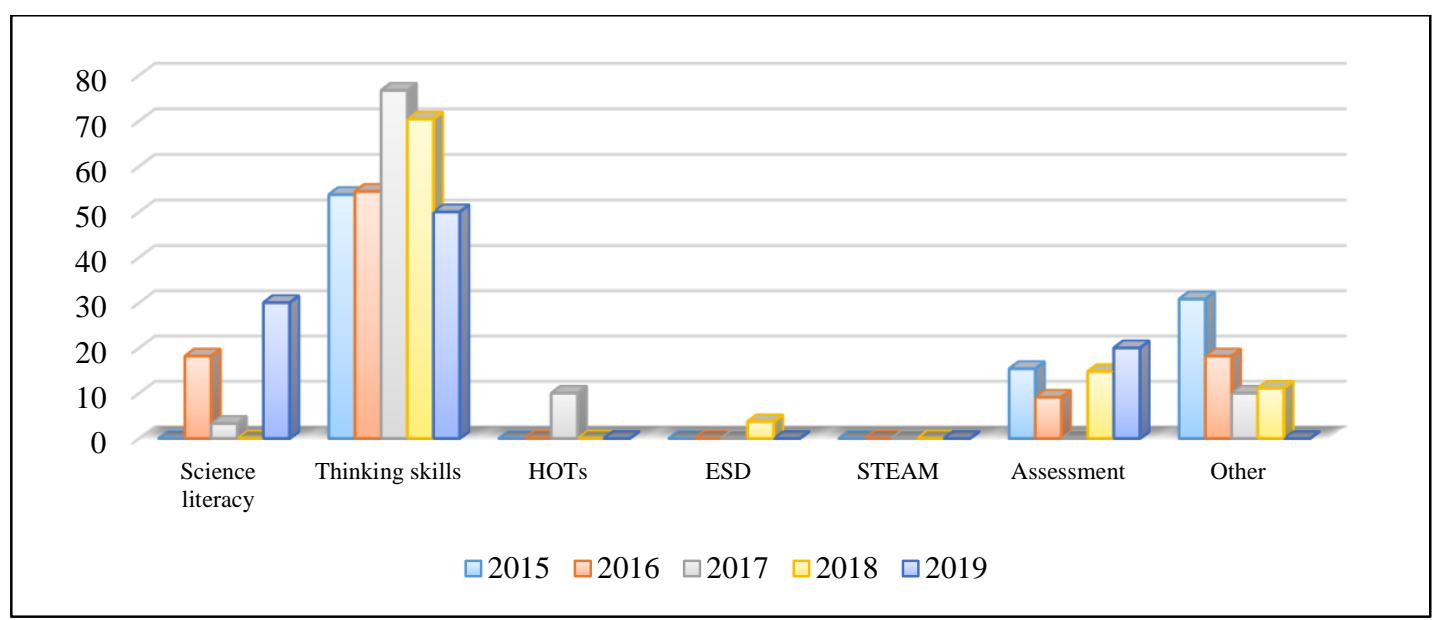

Figure 2. Graph of thesis profile percentage by area of research

Figure 2 shows that most student thesis profile trends from 2015 to 2019 use the field of thinking skills research. The thinking skills studied by each student include creative thinking skills, critical thinking, problem-solving, science process skills, and communicative skills. Student interest in researching the field of scientific literacy, assessment, and other fields is very small, and it can be seen in Figure. 2 that research fields other than thinking skills show a percentage below $30 \%$. So that there is a need for equity in the field of research for students in the following year so that there is variety and updating of student research in completing the final thesis.

Thinking skills are becoming a trend for students in conducting research. The existence of a relationship between the topic and the type of research studied by students is one of the causes of a large number of students in researching thinking skills. Learning innovations developed by students certainly aim to train or improve thinking skills such as creative thinking, critical thinking, problem-solving, science process skills, and communicative skills. In line with Sunarti \& Septiana (2019) research, problem-based learning innovation can improve students' creativity and communication skills. Problem-based learning innovation can train students' problem-solving skills (Hidaayatullaah et al., 2021, 2020). Sunarti (2020) environmental-based physics learning innovation on concept mastery.

The lack of student interest in researching scientific literacy, ESD, HOTs, and STEAM is shown in Figureure 2. Whereas development research by implementing learning innovations can be integrated with these variables to train thinking skills (Munawar et al., 2019). According to research conducted by Pradipta et al. (2021), the effectiveness of science learning tools based on Education Sustainable Development (ESD) can improve students' problem-solving skills. Research by Sutama et al. (2020) said that the development of the learning process integrated with STEAM could improve students' thinking skills.

The profile of the newness of the references used by students in completing the thesis is grouped according to two categories: the overall references used less than the last 10 years and more than the last 10 years from the year of thesis preparation. The update of the 20152019 master's degree science education student references is presented in Figure. 3. 


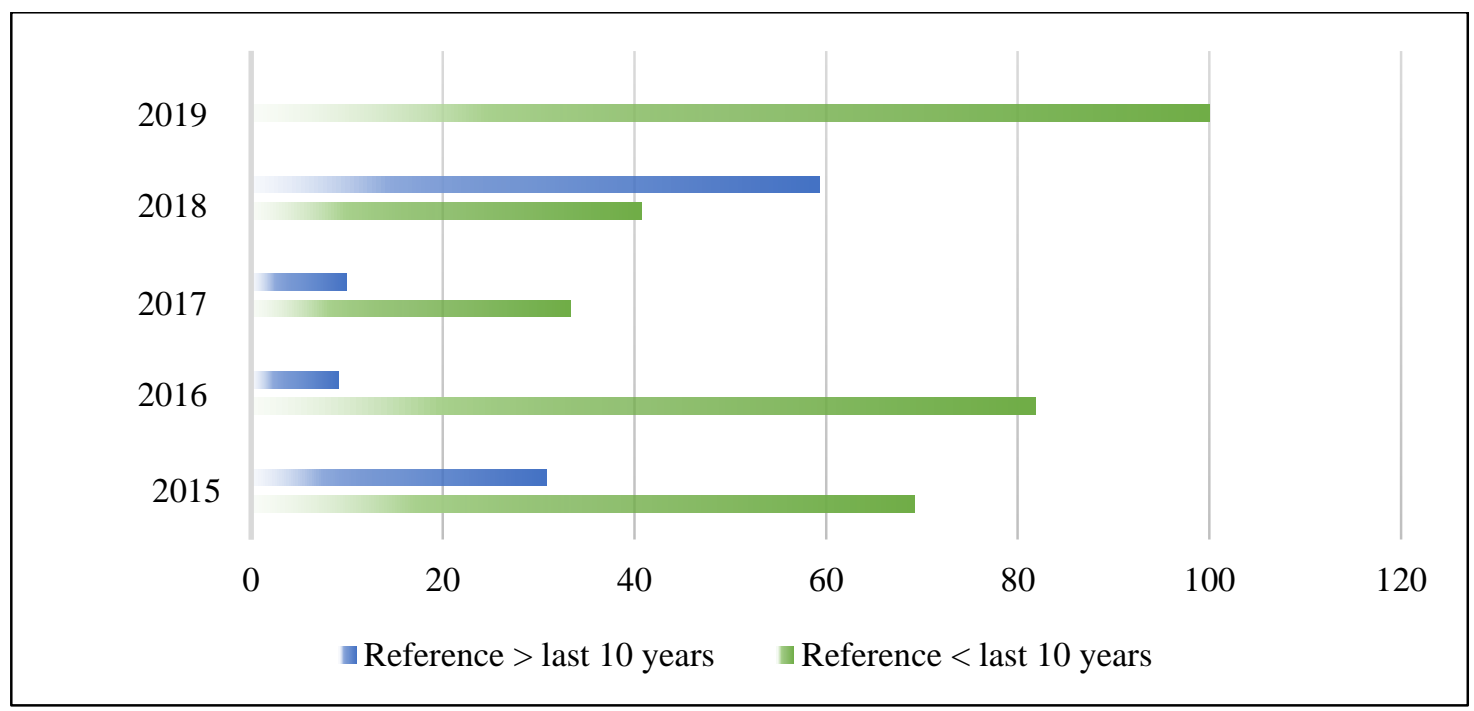

Figure 3. Percentage of the novelty of thesis references in 2015-2019

Figure 3 shows that most student thesis references from 2015-2019 have used updated references (no more than the last 10 years) with an average of more than 30 references used by each student to strengthen their research. However, in 2018 students still used a lot of references under the last 10 years. The novelty of references and the number of references used will greatly support the results of student research in compiling a study. The quality of a written work can be seen from one factor, the number of previous studies that support it, and a theory or study needs to be supported by relevant references (Andheska et al., 2020; Conrad, 2018; Givens, 2020; Jančaříková et al., 2020).

\section{Mapping of Student Publication Trends to Journals}

Mapping of publication trends for S2 Science Education students from the 2015-2019 class is grouped into 3 categories. The three categories are reputable international, international, and national. However, the data that the researcher will present is 4 . One additional category is missing data. The meaning of missing data is data that is not obtained by researchers when processing data. Missing data can be interpreted that researchers do not find articles published by students. The results of student publication trends from the 2015 to 2019 batch will be presented in Figure 4.

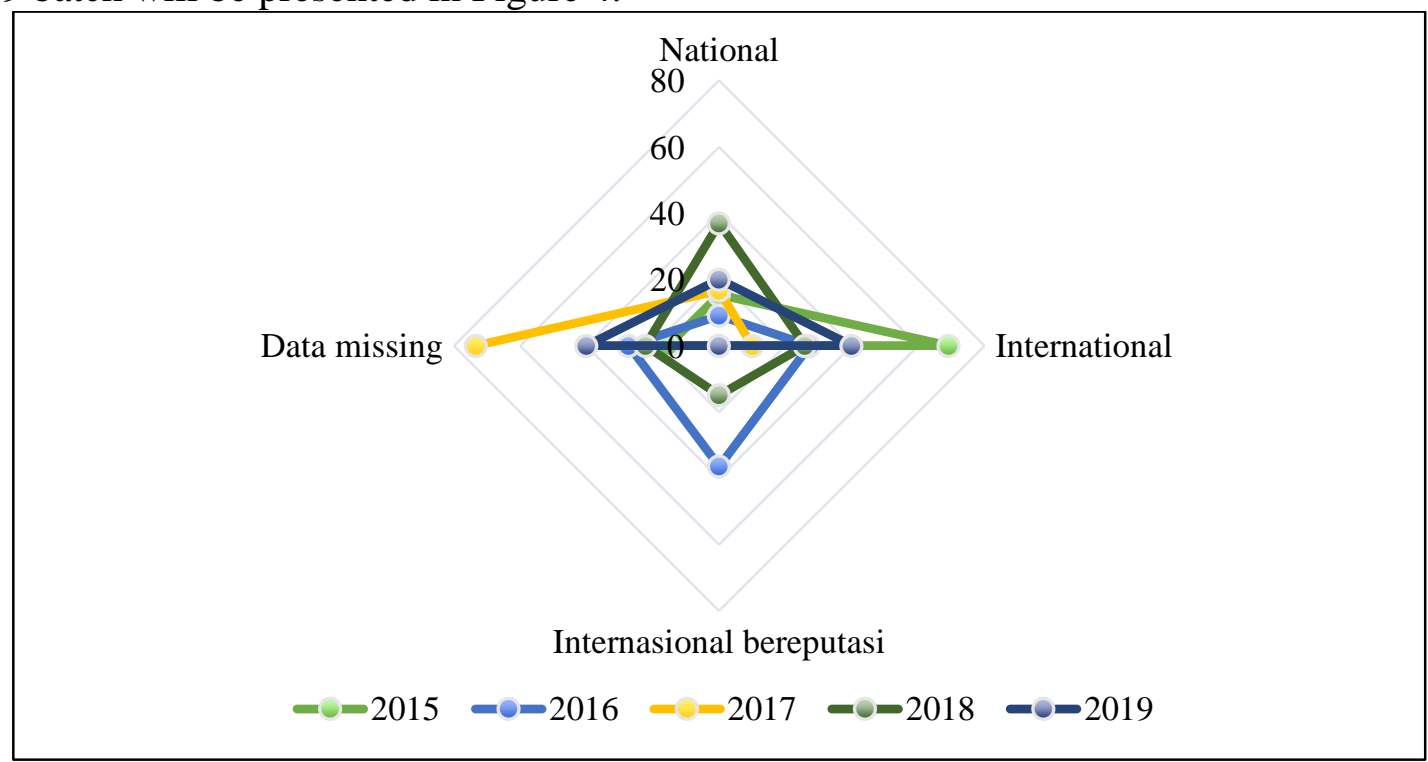

Figure 4. Graph of the percentage trend of student thesis publications 
Figure 4 shows that the largest percentage of student thesis publications from the 20152019 class were published in international journals. In 2015 the percentage published in international journals was approximately $70 \%$. And $15 \%$ of students who can publish in international journals are reputable. A small number of students publish articles in reputable international journals. So there is a need for further evaluation of the quality of student theses and publications so that further student research is of higher quality and the majority can publish in reputable international journals.

\section{Policy Recommendations to Improve the Quality of Student Thesis Writing}

The result of mapping the trend profile of the master's thesis in science education shows that there is a lot of student research on the development of learning by innovating learning models. Very few research topics on assessment development and learning media have been studied by students. Considering that many other educational themes are still lacking and may not have been touched at all, including curriculum or curriculum development, learning approaches such as HOTs, scientific literacy, ESD needs to be researched considering that masters in science education have an educational background. Therefore, to improve student research performance and to create the latest and varied research according to existing educational developments.

From the process and implementation of the research that has been carried out, it is hoped that there will be improvements and inputs for the future including the need for a more detailed Focus Group Discussion (FGD) related to educational themes that need to be studied according to existing educational problems and the need to map student research topics by supervisors to the theme. -Untouched research themes. So that for research, masters of science education students have novelties in the fields studied and are relevant to the needs of society and postgraduate science education study programs. Student research is carried out with the correct methodological process, not repetition, plagiarizing from previous work or research.

\section{CONCLUSION}

Based on the results of the studies that have been carried out, it can be concluded that the trend of thesis research for masters in science education is the majority using the type of development research with an average percentage of $98.18 \%$. The trend of student research topics by $83.2 \%$ focuses on innovative learning, with the majority of research in thinking skills. Lack of variety of research themes and research novelty in science education master's degree students in 2015-2019. So there is a need for more detailed FGDs relating to educational themes that must be studied according to existing educational problems, the need to map student research topics by supervisors to research themes that have not been touched at all, and the need to improve the quality of theses and publications for masters of science education.

\section{RECOMMENDATION}

The recommendation of this research is to explore the sample used further. Then a more in-depth analysis of the results of statistical research is needed.

\section{ACKNOWLEDGMENT}

Thank you to the state university of Surabaya for contributing to the thesis grant research as outlined in this article.

\section{REFERENCES}

Andheska, H., Suparno, S., Dawud, D., \& Suyitno, I. (2020). Writing motivation and the ability in writing a research proposal of generation $\mathrm{Z}$ students based on cognitive style. Journal for the Education of Gifted Young Scientists, 8(1). 
https://doi.org/10.17478/jegys.651436

Asmawan, A. (2017). Analisis kesulitan mahasiswa menyelesaikan skripsi. Jurnal Pendidikan Ilmu Sosial, 26(2), 51-57. https://doi.org/10.2317/JPIS.V26I2.3331

Barrot, J. S., Acomular, D. R., Alamodin, E. A., \& Argonza, R. C. R. (2020). Scientific mapping of English language teaching research in the Philippines: A bibliometric review of doctoral and master's theses (2010-2018): https://doi.org/10.1177/0033688220936764

Birney, L. B., Evans, B. R., Kong, J., Solanki, V., Mojica, E. R., Kondapuram, G., \& Kaoutzanis, D. (2021). A case study of undergraduate and graduate student research in STEM education. Journal of Curriculum and Teaching, 10(1). https://doi.org/10.5430/jct.v10n1p29

Brata, W. W. W. (2015). Analisis skripsi guna membangun roadmap penelitian prodi pendidikan biologi. Jurnal Pelita Pendidikan, 3(4). https://doi.org/10.24114/JPP.V3I4.4009

Conrad, S. (2018). The Use of Passives and impersonal style in civil engineering writing. Journal of Business and Technical Communication, 32(1). https://doi.org/10.1177/1050651917729864

Daud, A. M., Omar, J., Turiman, P., \& Osman, K. (2012). Creativity in science education. Procedia - Social and Behavioral Sciences, 59, 467-474. https://doi.org/10.1016/J.SBSPRO.2012.09.302

Desi Wulandari. (2019). Penerapan model pembelajaran inkuiri terbimbing menggunakan STEM untuk meningkatkan keterampilan berfikir kreatif pada materi pemanasan global. Inovasi Pendidikan Fisika, 8(3).

Givens, C. (2020). Analyzing writing style and adapting to a new writing culture: A teaching practice. Journal of Academic Writing, 10(1), 213-220. https://doi.org/10.18552/joaw.v10i1.582

Greenberg, K. P. (2015). Rubric use in formative assessment: a detailed behavioral rubric helps students improve their scientific writing skills. Teaching of Psychology, 42(3), 211-217. https://doi.org/10.1177/0098628315587618

Hammond, L. (2021). The activity of student research: using activity theory to conceptualise student research for master's programmes. Studies in Higher Education, 46(6). https://doi.org/10.1080/03075079.2019.1666261

Hidaayatullaah, H. N., Dwikoranto, Suprapto, N., Mubarok, H., \& Wulandari, D. (2020). Implementation of problem based learning to train physics students' problem solving skills. Journal of Physics: Conference Series, 1491(012053), 1-8. https://doi.org/10.1088/1742-6596/1491/1/012053

Hidaayatullaah, H. N., Suprapto, N., Hariyono, E., Prahani, B. K., \& Wulandari, D. (2021). Research trends on ethnoscience-based learning through bibliometric analysis: Contributed to physics learning. Journal of Physics: Conference Series, 2110(012026), 1-8. https://doi.org/10.1088/1742-6596/2110/1/012026

Jančaříková, R., Povolná, R., Dontcheva-Navratilova, O., Hanušová, S., \& Němec, M. (2020). An academic writing needs analysis of czech university graduate students. Discourse and Interaction, 13(1). https://doi.org/10.5817/DI2020-1-42

Laptev, V., \& Larchenkova, L. (2016). Scope of thesis research in the area of physical science education. Voprosy Obrazovaniya, 2016(4). https://doi.org/10.17323/1814-95452016-4-31-58

Meza, P., \& Nascimento, A. (2018). Identifying a research gap in humanities: Variation in theses and research papers. Alpha, 47, 211-223. https://doi.org/10.32735/S0718220120180004700177

Munawar, M., Roshayanti, F., \& Sugiyanti, S. (2019). Implementation of STEAM (Science Technology Engineering Art Mathematics) - based early childhood education learning in Semarang city. CERIA (Cerdas Energik Responsif Inovatif Adaptif), 2(5). 
https://doi.org/10.22460/ceria.v2i5.p276-285

Pradipta, D. D., Madlazim, \& Hariyono, E. (2021). The effectiveness of science learning tools based on Education Sustainable Development (ESD) to Improve problem-solving skills. IJORER : International Journal of Recent Educational Research, 2(3), 342-353. https://doi.org/10.46245/IJORER.V2I3.113

Rachmatullah, A., Diana, S., \& Rustaman, N. Y. (2016). Profile of middle school students on scientific literacy achievements by using scientific literacy assessments (SLA). AIP Conference Proceedings, 1708(1), 080008. https://doi.org/10.1063/1.4941194

Rosba, E., Zubaidah, S., Mahanal, S., \& Sulisetijono. (2021). College students' critical thinking skills and creativity. AIP Conference Proceedings, 2330(1). https://doi.org/10.1063/5.0043294

Ruhaliah, R., \& Hernawan, H. (2019). Sundanese Oral Tradition Research MapinUndergraduate Theses of Students of Department of Sundanese Education of FPBS UPI. https://doi.org/10.4108/EAI.29-8-2019.2289005

Sarirah, T., \& Saputri, A. C. (2019). Academic self-efficacy as a predictor toward decisional procrastination among college students preparing a thesis in Indonesia. Journal of Advanced Research in Social Sciences and Humanities, 4(1). https://doi.org/10.26500/JARSSH-04-2019-0104

Shustin, B. N., Baranov, V. N., \& Noskova, V. F. (2019). Analysis of relevant thesis research directions in physical education and sport sector in 2017-2018. Teoriya i Praktika Fizicheskoy Kultury, 12, 96-98.

Sudarisman, S. (2013). Analisis Kecenderungan Metodoe Penelitian Skripsi Mahasiswa di Program Studi Pendidikan Biologi UNS. In Proceeding Biology Education Conference: Biology, Science, Enviromental, and Learning, 10, 1. URL: https://jurnal.uns.ac.id/prosbi/article/download/6348/5732

Sunarti, T., \& Septiana, D. A. (2019). The effect of problem-based learning with gallery walk strategy to creativity and communication skills. Advances in Computer Science Research, 95, 144-148. https://doi.org/10.2991/MISEIC-19.2019.40

Sunarti, T., Sunarti, T., Hariyono, E., Setyarsih, W., Prahani, B. K., \& Suyidno, S. (2020). The impact of environmental-based physics learning on students' concept mastery and ecopreneurship management. Prisma Sains : Jurnal Pengkajian Ilmu Dan Pembelajaran Matematika Dan IPA IKIP Mataram, 8(2), 91-98. https://doi.org/10.33394/jps.v8i2.3016

Susetyo, \& Noermanzah. (2020). Model of literature review in research thesis of students education master program at FKIP Bengkulu university. International Journal of Scientific and Technology Research, 9(2).

Sutama, Prayitno, H. J., Ishartono, N., \& Sari, D. P. (2020). Development of mathematics learning process by using flipped classroom integrated by STEAM education in senior high school. Universal Journal of Educational Research, 8(8), 3690-3697. https://doi.org/10.13189/ujer.2020.080848

Wulandari, D., Madlazim, \& Ermawati, F. U. (2019). Analysis ability thinking fluency of students in global warming materials through inquiry learning model. Prosiding Seminar $\begin{array}{llll}\text { Nasional Fisika } & \text { (SNF), 60-65. }\end{array}$ https://fisika.fmipa.unesa.ac.id/proceedings/index.php/snf/article/view/107

Zhang, W. (2020). The research on the theme and development trend of mobile learning in china in the past ten years. Journal of Physics: Conference Series, 1453(1). https://doi.org/10.1088/1742-6596/1453/1/012133

Zulkifli, L., Jekti, D. S. D., \& Ramdani, A. (2015). Analisis kecenderungan penelitian tesis mahasiswa pada program studi magister pendidikan IPA Universitas Mataram. Jurnal Penelitian Pendidikan IPA, 1(1), 14-23. https://doi.org/10.29303/JPPIPA.V1I1.2 